Juliusz Grzybowski

\title{
KRÓTKI RZUT OKA NA TRZY GRECKIE OBRAZY CHOREOGRAFII
}

Zacznijmy od głównego pojęcia i przyjmijmy zuchwale, że ci, którzy owo pojęcie ukuwali, wiedzieli, co robią. Założenie jest, rzecz jasna, nie tylko zuchwałe, ale i błędne, słowa bowiem, jak i zresztą wszystkie inne wynalazki, nigdy nie przedstawiają się w pełni, zanim nie zostaną wprowadzone w życie. Stąd moje badania językowe z konieczności obarczone będą pewnym drobnym błędem, pytając się bowiem o słowo, będę niejako zakładał, że nazywanie nie dokonuje w tym, co nazywane żadnych zmian. Mówiąc inaczej: będę zakładał, że to, co nazwa nazywała, było tym czymś, zanim zostało nazwane. A zatem słowo choreografia, jak wiemy, składa się z dwóch słów - możemy je roboczo przetłumaczyć jako pisanie tańca. Oczywiście tłumaczenie jest robocze i domaga się uściślenia, nie wiemy bowiem, o jakie pisanie chodzi, ani też nie za bardzo wiemy, czy to, co $\mathrm{w}$ słowie choreografia chciałoby się przedstawić jako taniec, jest nim istotnie. Jednym słowem wpadamy w swoiste rozchwianie definicyjne, zdaje nam się bowiem często (żeby nie powiedzieć: zdaje nam się zazwyczaj), że tańca się od choreografii oddzielić nie da i że każdy taniec, jeśli ma być tańcem zaistniałym - to znaczy takim, który można wskazać i jakoś, prowizorycznie choćby, opisać - jest tańcem, w którym już jakiś choreograf swoje palce maczał. Jednak nawet jeśli mielibyśmy uznać, że poruszamy się na gruncie istnień wyabstrahowanych, a zatem jakoś przecież zawsze, na skutek oddzielenia i związanej z tym oddzieleniem odległości, zamazanych, pytanie jest zbyt kuszące, aby powątpiewać w jego sensowność. Choć, jak wszystkie wyprawy teoretyczne, jest takie pytanie obciążone potężnym ryzykiem. Słowa bowiem jakoś tworzą rzeczy. Chciał nie chciał.

Założenie, które przyświecało mi podczas pracy nad artykułem, można zatem sformułować następująco: taniec i choreografia to dwie różne sprawy i co więcej - przyjąłem, że do pewnego stopnia jesteśmy w stanie przyglądać się im w odosobnieniu. Co więcej, przyjąłem, zdaje się na przekór wielu uczonym, że takie przyglądanie się tym dwu rzeczom w odosobnieniu ma szansę być przyglądaniem sensownym. Oczywiście pierwsze, co się przy tak postawionej kwestii pojawia, to pytanie o taniec pozbawiony choreografii - czym jest? Kłopot polega na tym, że poszukując takiego tańca, powinniśmy, ufni w wykładnię arystotelesowych kategorii, odnaleźć nieukształtowaną materię, która to później dopiero 
będzie określana formą. A zatem na początku kusi nas opozycja materii i formy.

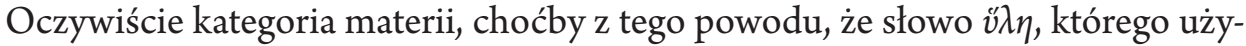
wa na oznaczenie materii Arystoteles, znaczy również w języku greckim las, stwarza wiele zachwycających kłopotów, dla nas jednak najważniejszym zdaje się ów, wedle którego o materii nie można powiedzieć, że jest czymś, każde bowiem coś, będąc tym czymś, a nie czymś innym, jest już z konieczności jakoś uformowane. Bez względu na to jednak, na jak bardzo nieuformowany taniec byśmy trafili, czymś on jednak będzie i co więcej, a co sprawia nam przecież największe kłopoty, bez względu na rozległą różnicę zdań, jaka nas zapewne w tej kwestii dzieli, nie tylko uznajemy, że taniec wciąż się zdarza i że czasami, niestety, nie zdarza się tam, gdzie zdarzyć się powinien. Skoro taniec czasem nie zdarza się tam, gdzie zdarzyć się powinien, winniśmy przyglądać mu się z troską, to, co się bowiem może od czasu do czasu nie zdarzyć, może się też przestać wydarzać w ogóle. Słowo wydarzać w języku polskim znaczy zresztą „ukazywanie się daru”, a dar jest zawsze jakoś przecież nieoczekiwany. Mówiąc inaczej, taniec może być i nie być, zarówno w sensie szczegółowym, jak i w sensie ogólnym. Co więcej, pomimo rozległej różnicy zdań wciąż nie potrafimy powiedzieć, i chyba nawet w odpowiedni sposób zapytać, co sprawia, że jakiś układ choreograficzny tańcem jest, a co sprawia, że nim nie jest.

Żeby może wyraźniej powiedzieć, co mam na myśli, pozwolę sobie zacytować swojego dawnego nauczyciela tańca, Witolda Jurewicza, który często podczas prób do spektakli tak nam oto mówił: „Pięknie wykonujecie wszystkie elementy, dobrze by było, gdybyście jeszcze zaczęli tańczyć”. Skoro jednak taniec jest czymś, nie można mówić o nim, że jest tym, co nieukształtowane jako takie, a zatem być może powinniśmy w tym miejscu wycofać się z arystotelesowej kategoryzacji? Może, jednak przegapilibyśmy pewną podpowiedź. O ile bowiem materia, wedle Arystotelesa, nie ukazuje się sama przez się, a ukazuje się jedynie jako ukształtowana, jest jeden moment, w którym głos materii zdaje się jakoś formie wymykać. Arystoteles nazywa ten moment nieskończonością (Fizyka, 207a, w. 21-26). Jest to, rzecz jasna, z jednej strony miejsce, w którym forma traci siłę, a zatem wpada w kłopot, o ile bowiem formowanie zwykle tyleż dopuszcza, co zasłania i niejako przecież bierze władzę, tutaj jednak każde nałożenie formy skutkuje wymknięciem. Rzecz jasna każde wymknięcie znowu napotyka formę i tak w nieskończoność, stąd nie ukazuje się żadne takie coś, o czym moglibyśmy powiedzieć, że jest czymś pozbawionym formy, o tyle samo wymykanie się i, czego by nie powiedzieć, jakoś anonsująca się istność, która powoduje w nas dobrze znane zawroty głowy, jest głosem formy dostrzegającej swoją własną nieobecność. Z jednej strony słabość formy, z drugiej - wraz z tą słabością i w niej ukazująca się siła. Siła czego? Chciałoby się rzucić tutaj kilka nasuwających się potężnych uogólnień, ale stykamy się, chcąc nie chcąc, z jakąś niepisaną pradawną ontyczną, czy może ontologiczną, umową, która chce się przedstawić nie tyle jako element, ile jako źródło. 


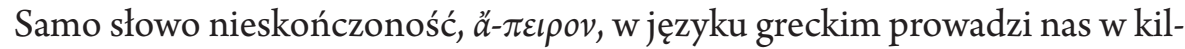
ku kierunkach. Jak się zdaje, i wszyscy znani mi językoznawcy idą tą drogą (Lidell-Scott 1996; Beekes 2010; Chantraine 1968; Frisk 1960; Matthiae 1861), $\ddot{\alpha}-\pi \mathcal{E} ı \rho$ jest słowem zaprzeczonym, to znaczy: początkowe alfa zwykle określone jest jako alpha privativum. Póki co przyjmijmy ogólnie przyjęte ustalenia. Przypomnijmy sobie jednak, jak meandrująca była gra między materią i formą, która pojawiała się w ramach ukazywania się nieskończoności - nie powinniśmy zatem zbyt pochopnie tego zaprzeczenia odstawiać jako już definitywnie przejrzanego. Przypomnijmy sobie zresztą, jak meandrująca była (przynajmniej w języku greckim) gra między przeczeniem i twierdzeniem. Druga część słowa ă- $-\pi \varepsilon l \rho o v$ wiedzie nas albo ku słowu $\pi \varepsilon$ pa - „kres”, a zatem mielibyśmy wykładnię, wedle której tym, co nieskończone, byłoby to, co nie zna kresu; albo też, jeśli w drugiej części

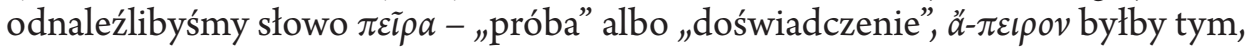
czego nie można doświadczyć czy wypróbować, w tym znaczeniu, w którym mówimy o doświadczeniu, które mogłoby stać się podstawą nauki czy wiedzy. Każda próba byłaby czymś jednorazowym i niepowtarzalnym. Nie można by się jej było zatem wyuczyć, a jedynie można by do niej podprowadzić. Co więcej, każda taka próba z założenia byłaby czymś pierwszym i zarazem ostatnim, nieoczekiwanym, ale przecież czymś najbardziej własnym, co być może najwyraźniej spostrzegamy wtedy, kiedy twierdzimy, że improwizacja jest jakimś poza sobą siebie odnajdywaniem. Skoro zatem siebie samego możemy, a nawet jakoś musimy, poza sobą odnajdywać, trafiamy rzecz jasna na moment, w którym tożsamość staje się pulsowaniem, czy może zawahaniem. Tu i tam. Tutaj i gdzie indziej. Możemy w tym miejscu wytłumaczyć się trochę z naszych wątpliwości względem rozpoznania $\mathrm{w} \ddot{\alpha}$ - $\pi \varepsilon i \rho o v$ alpha privativum, to znaczy zaprzeczenia. W języku greckim $\pi \varepsilon \tilde{\imath} \rho a$, czyli „próba”, znaczy taki kres naszych umiejętności bądź kompetencji, w którym z jednej strony nasze umiejętności stają się największymi naszymi kompetencjami, z drugiej, miejsce, w którym w największym stopniu ryzykujemy utratą kompetencji; mówiąc inaczej, $\pi \varepsilon i \tilde{\rho} a$ znaczy specyficzne miejsce, w którym wiedza i los jakoś się ze sobą splatają. Jeśli pomyślelibyśmy próbę - $\pi \varepsilon i ̄ p a-w$ ten sposób, alpha privativum zaczyna $\mathrm{z}$ wolna przedstawiać się jako alpha intensivum, á- $-\pi \varepsilon l \rho o v$ nie byłoby zatem zaprzeczeniem próby, ale byłoby zatopieniem się w próbie. Te drogi, którymi ă- $\pi \varepsilon \iota \rho o v$ droczy się z etymologią, są rzecz jasna drogami podstawowymi, czy nawet trochę arbitralnie dobranymi, niech posłużą jedynie za wprowadzający zarys. Tyle informacji etymologicznych. Poszukajmy teraz egzemplifikacji, czy może inaczej: poszukajmy teraz kilku obrazów.

Na pierwszy obraz naprowadza nas Arystoteles, kiedy mówi, że nieskończonością ( $\ddot{a}-\pi \varepsilon \imath \rho o v)$ jest „to, co może być śledzone, jednak proces ten nie da się doprowadzić do końca” (Fizyka, 204a, w. 4-5). I o ile Arystoteles pod obraz nas podprowadza, o tyle wątpliwości nie pozostawiają już wykładnie słownikowe, szczególnie ta, którą daje Augustus Matthia: „ä $\varepsilon \varepsilon ı \rho \varsigma$ nazywa się każde miejsce bądź rzecz, z których nie masz wyjścia, skąd nikt cię nie wydostanie (Labirynt)” 
(Matthiae, 1861). Obraz jest o tyle pouczający, co zwodniczy, nic bowiem jaśniejszego pod słońcem; również autor niniejszego tekstu w swoim szale pisarskim o labiryncie napisał tyle, że można by z tego nie tylko sporządzić solidnej długości artykuł, ale założyć kierunek uniwersytecki (Grzybowski 2011, 2013, 2015). Żeby było jasne - w tym szale pisarskim dotyczącym labiryntu autor niniejszego tekstu nie jest bynajmniej odosobniony. No dobrze: labirynt, czyli co? Obrazy się nasuwają, kłopot w tym, że większość z tych obrazów jedynie w niewielkim stopniu spełnia wymogi definicyjne. Jeżeli bowiem labirynt miałby być miejscem, z którego nie ma wyjścia, nie mógłby on być siecią splątanych ścieżek, bez względu bowiem na to, jak bardzo by owe ścieżki nie były splątane, można by było, choćby przypadkiem, z owej sieci splątanej znaleźć wyjście. A zatem mielibyśmy słabszą wersję, miejsce, do którego można wejść, ale z którego wyjść trudno. Pomiędzy niemożliwym a trudnym zdaje się, że różnica jest zbyt wielka, byśmy ją zaraz pochopnie mieli odpuszczać. Tym bardziej, że dobrze nam znany mit założycielski labiryntu mówi wyraźnie, że gdyby nie Ariadne, Tezeusz by z labiryntu nie wyszedł. Odpuszczając wersje futurystyczne z wymiarami zakrzywionymi i pętlami czasoprzestrzennymi jako jednak anachroniczne, pozostaje nam skupić się pokrótce na dwóch możliwych odpowiedziach, tym bardziej że opowiadania wokół tych dwóch odpowiedzi domaga się mit. Hades i plac taneczny. Co do Hadesu sprawa zgodności z definicją jest, zda się, póki co rozstrzygnięta; więcej kłopotów sprawia być może plac taneczny. Plac taneczny, a zatem miejsce, na którym czy w obrębie którego odbywa się taneczne przedstawienie. Oczywiście argumentacja winna być bardziej sumienna, ale pokuśmy się o przykład, tym bardziej że mamy go właściwie pod ręką. Niniejszy tekst zaistniał w bardzo zbliżonej formie jako wystąpienie konferencyjne, dla jego autora wystąpienie o tyle przełomowe, że pierwsze wygłoszone w całości w języku angielskim, czy może raczej w języku, który starał się angielskim językiem być i na skutek życzliwości innych uczestników konferencji jako angielski był rozpoznawany. Mówiąc krótko: bałem się strasznie i im bardziej mój angielski przestawał być angielskim, i im więcej widziałem w oczach słuchaczy obaw, a mniej zainteresowania - tym większy stawał się mój lęk. Rósł wytrwale, by w końcu przerodzić się w strach, właściwie paniczny. Niewiele brakowało, abym uciekł. Oczywiście wystąpienie konferencyjne nie jest przedstawieniem tanecznym, rysuję jedynie pewną analogię. A zatem uczuciem, którego doznaje każdy występujący publicznie w jakimś prowizorycznie chociaż sformalizowanym kształcie, jest uczucie niemożliwości ucieczki, nie tyle niemożliwości opartej na przemocy widowni (choć rola widowni, zgodnie czy niezgodnie z jej wolą, jest z jakąś przemocą rzecz jasna związana), ile na niemożliwości, którą należałoby nazwać właściwie niemożliwością fizyczną, nie istnieje bowiem miejsce, które mogłoby być określone jako miejsce ucieczki, akt odejścia, zamiast zostać przyjętym, zostałby poddany interpretacji. A interpretacja dowodzi nieusuwalnej różnicy. Oczywiście najbliżej sedna będziemy, jeśli poszukamy placu tanecznego, pytając się o scenę. Scena mimo tego, 
że jest jakimś miejscem i co więcej jest jakimś miejscem ograniczonym (w końcu widownia znajduje się na zewnątrz sceny, a zatem jakoś ją ogranicza), ukazuje się z drugiej strony jako miejsce nieskończone, rzecz jasna, jak by to powiedział Arystoteles, nieskończone potencjalnie, ale nie możemy wskazać takiego miejsca w przestrzeni, w którym scena kończyć by się musiała definitywnie, a i definitywnie musiałby się zaczynać świat pozasceniczny. Jak pisałem, zarówno Hades, jak i plac taneczny pojawiają się w micie zamiennie. Minotaur i ofiara, śmierć. Przypomnijmy może o tych archeologach, którzy w pałacu Minosa w Knossos widzieli jeśli nie cmentarz, to po prostu świątynię umarłych (Wunderlich, 2003). Ale przypomnijmy też sobie o tych odnogach mitu, w których to Tezeusz miast do Knossos udaje się do Hadesu i miast Ariadny próbuje uwieść Persefonę. Z drugiej strony mamy opis tańca Ariadne na tarczy Achillesa, mamy wazę François, na której Tezeusz, prowadząc chór taneczny, zmierza ku czekającej na niego na plaży Ariadne. Sam taniec Ariadne i Tezeusza domaga się rzecz jasna głębszej analizy historycznej, póki co zwróćmy uwagę jedynie na kilka spraw. Po pierwsze, mamy do czynienia z momentem rozstrzygającym, to znaczy z takim momentem, w którym zapadają decyzje dziejowe, czyli takie, które później będzie trzeba traktować jako grunt dla wszelkich innych decyzji. Trafiamy zatem do miejsca, wokół którego wszystkie inne miejsca zdają się być skupione. Po drugie, trafiamy do miejsca, które wciąż w niewytłumaczalny dla nas sposób posiada swoje prawodawstwo pozwalające rozstrzygać wewnątrz niego to, co rozstrzyganiu poza tym miejscem, na zewnątrz, się wymyka. Kilka obrazów pomocniczych: badania archeologiczne w Grecji wskazują na to, że plac taneczny poprzedza agorę (Zwolski 1968, s. 6), wystarczy wsłuchać się w owe homeryckie i nie tylko homeryckie epitety miast,

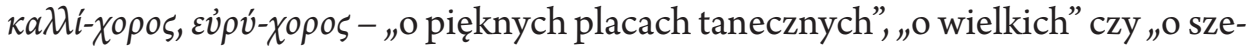
rokich placach tanecznych”. Kolumna tancerek w Delfach, zwana inaczej kolumną akantową, na której szczycie znajdowała się kopia Omphalosa, kamienia, który w Delfach uważano za pępek świata. Kim są tancerki? O, tu spór się toczy. Hory? A może Menady? Każda odpowiedź będzie wybrakowana, takich trójek tańczących dziewcząt znali bowiem Grecy wiele i jest w tym obrazie owej tańczącej trójki coś, w czym dostrzegali oni moment, w którym koło pozostaje kołem bądź kiedy staje się spiralą - punkt dziejowy, w którym rozchodzą się ścieżki bogów i ludzi, wieczności i czasu. Trochę sprawę upraszczając: środek świata podtrzymywany jest przez trzy tańczące dziewczyny. Owszem Hory, Charyty, Hesperydy, Mojry czy Erynie, odcieni mamy wiele, z drugiej strony owa być może najsłynniejsza trójka - Artemida, Atena i póki co bezimienna lub skrywająca swe imię dziewczyna, Kore, która później stanie się Persefoną. Owszem, ale i Gorgony przecież, z których najmłodsza śmiertelna Meduza, wiodą nas do tej samej opowieści (Topper, 2010). Trochę jesteśmy winni każdemu z tych obrazów więcej czasu i miejsca, ufamy po cichu, że każdy z nich stanie się poniekąd malowidłem wazowym, które nie tyle będzie przekazywać informację, co będzie budzić opowieść. To jedno, ale przede wszystkim chciałem pokazać, że myśl, wedle której w tańcu 
rozstrzygają się sprawy dla państwa najważniejsze, nie była w Grecji bynajmniej poglądem odosobnionym, ale zda się ogólnie przyjętym. Stąd przyjmuję, wbrew większości ustaleń na ten temat, że przedstawiony w osiemnastej księdze Iliady na zakończenie opisu tarczy Achillesa taniec Ariadne zajmuje na niej miejsce centralne (Grzybowski 2013). Wokół tańca wszystko inne się kręci i moglibyśmy nazwać ten opis opisem kosmologicznym, z tym drobnym zastrzeżeniem, że o ile w systemie zarówno geocentrycznym, jak i heliocentrycznym wszystko, co wokól, porusza się ruchem kołowym, o tyle na obrazie tarczy Achillesa wokoło płynie jedynie Okeanos - a cała reszta porusza się ruchem spiralnym.

No dobrze, oszołomieni widokiem tańczących na kwiecistej łące trzech dziewcząt zgubiliśmy postać choreografa. Wróćmy zatem w to miejsce, w którym znaleźć go powinniśmy. Dedal. Samo imię pochodzi od greckiego czasownika $\delta a ı \delta a \lambda \varepsilon ́ \omega$ i znaczy tyle, co „mistrz” czy „twórca przemyślny”. Tekst Iliady, na który się powoływaliśmy i w którym pojawia się opis tańca Ariadne, może nas powieść dwiema drogami, dopuszczalne są bowiem dwie możliwości tłumaczenia (Kirk 1991, t. V, s. 228). A zatem albo Dedal wybudował posadzkę dla Ariadne, albo też utworzył chór taneczny, utworzył lub nadał mu misternie spleciony kształt. Tłumaczenie słowa $\pi$ oíkı $\lambda \mathcal{E}$, które tutaj nieporadnie staramy się wtłoczyć w polszczyznę, samo domagałoby się tłumaczenia. Wiedzie ono bowiem, podobnie zresztą jak słowo $\delta a ı \delta a \lambda \varepsilon ́ \omega$, ku rzeczywistości, w której wielość nie dała sobie jeszcze narzucić prymatu jedności. Do tej rzeczywistości, w której dziesiątkami

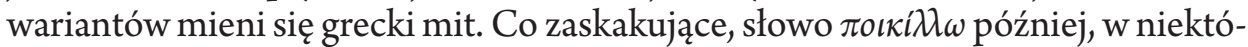
rych ze swoich przedstawień, wieść będzie samo w sobie, niezależnie od związków z Dedalem, do labiryntu. No dobrze, o tym, że Dedal wybudował labirynt, wiemy. Wiemy też, że w labiryncie został uwięziony Minotaur. Kim był Minotaur, jeśli labirynt miałby się stać placem tanecznym czy Hadesem? Kilka odpowiedzi się narzuca i te najbardziej narzucające się należałoby, być może, powściągnąć. Przyjrzyjmy się jednej.

Minos był synem Dzeusa. To raz. Dwa, Minos z Dzeusem miał pomimo pokrewieństwa układy raczej oficjalne, to znaczy Dzeus się pojawia w życiu Minosa raczej $\mathrm{w}$ ramach wielkich świąt państwowych, wizyt $\mathrm{w}$ jaskini i uroczystym odnowieniu władzy królewskiej. Kiedy Minos chce się podzielić z jakimś bogiem skrywanymi w swoim wnętrzu wątpliwościami, raczej wybiera Posejdona. Tak jest i wtedy, kiedy to właśnie jego prosi o dowód swojego boskiego rodowodu. Jestże Dzeus moim ojcem, czy nie jest? Jeśli jest, niech z morza wyjdzie wspaniały biały byk. Jak wyjdzie z morza, złożę go natychmiast w ofierze. Minos, zatopiony w swoich wątpliwościach, trochę wierzy, a trochę nie wierzy, może nawet sam nie słyszy swojego głosu, który zdążyli usłyszeć bogowie, stąd zapewne dostrzega byka dopiero po pewnej chwili, tej chwili, która później, jeszcze u Kartezjusza, będzie rozpoznawana jako miejsce powstania błędu, ale, może to zabrzmi hulaszczo, jest ta chwila przecież zawsze początkiem opowieści, miejscem narodzin świata. Przesunięciem, nie trafieniem. Plutarch, który opowiada o tańczonym 
wciąż w jego czasach na Delos tańcu labiryntowym zwanym geranos - „tańcem żurawi", który to miał pierwszy na Delos zatańczyć Tezeusz, wymienia tylko dwa elementy dla tego tańca charakterystyczne: aneliksis i paralaksis (Plutarch, Tezeusz, r. 21, 1-2). O ile aneliksis wiedzie nas ku spirali, o tyle paralaksis wiedzie nas właśnie ku wyminięciu i przeoczeniu. A zatem to, co później ukaże się w labiryncie, anonsuje się już na początku. A zatem Minos i byk. Byk jest, czego nie przewidział i jakoś przewidzieć w końcu Minos nie mógł, piękny. Wątpliwości dotyczące ofiary pojawiają się od zawsze i sama ofiara jakąś wątpliwością jest od zawsze naznaczona. Wątpliwością co do zasięgu, metody i skuteczności działania. Stąd pojawiające się w głowie Minosa wnioskowania dowodowe, które szybko prowadzą go do stwierdzenia, że sto innych byków na pewno bogu bardziej przypadnie do gustu. Oczywiście Minosa konstrukcje dowodowe bogu do gustu nie przypadają i spada na Minosa kara, która wiedzie przez wspaniałego białego byka. Mianowicie Pazyfae, żona Minosa, zaczyna do tego byka pałać iście zwierzęcą żądzą. Pojawiają się problemy moralne, ale tam, gdzie pojawiają się bogowie, czemu jeszcze przyjrzymy się trochę dokładniej, problemy moralne przestają być problemami, stąd po chwilowych problemach moralnych pozostają niebawem jedynie problemy techniczne. No bo w końcu sprawa jest technicznie skomplikowana. I tutaj właśnie pojawia się Dedal, o którym Eustathius, bizantyjski autor komentarza do Iliady, mówi, że „kiedy kobiety wpadały w sidła miłości, on dostarczał im pomocy

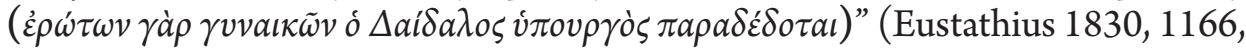
t. IV, s. 102). Dedal, jak powiadają, stworzył drewnianą krowę, w której skryła się Pazyfae, i co tu dużo opowiadać - mit, przynajmniej w takich sytuacjach, nie zna innych zbliżeń, aniżeli zbliżenia brzemienne, stąd i z tego zbliżenia Pazyfae wychodzi brzemienną. Tak rodzi się Minotaur. I co się dzieje? Wstyd w rodzinie, jasne, i to wstyd wielki. Jaką zatem przyjąć strategię? Zabić? Ukryć? Dedal buduje Labirynt i w tymże Labiryncie, który pojawia się z jednej strony jako grób, a z drugiej jako więzienie (mamy poczucie, że definicje tych dwu miejsc jakoś na siebie nachodzą), ukrywa Minos Minotaura. No dobrze, zdawać by się mogło, że cechą nieodłączną ukrycia winna być jakaś kontrola informacyjna. Ukrywamy, aby temu, co na zewnątrz, odmówić dostępu albo przynajmniej dostęp utrudnić. Tymczasem Minos nie tylko nie kontroluje przepływu informacji, ale jeszcze sam informacje tworzy. Oczywiście, że układy o podległości między Atenami i Kretą mogą grać jakąś rolę, ale - u licha! - dlaczego siedmiu chłopców i siedem dziewczynek musi ginąć w Labiryncie? Staramy się zrozumieć, stąd nie tylko można, ale i trzeba nam zarzucić próbę racjonalizacji, ale przecież mogli Ateńczycy ginąć w innych okolicznościach, jeśli rzeczywiście mieliby ginąć, a Minotaur, jeśli takie były jego w Labiryncie potrzeby, mógł się posilać jakimiś bezimiennymi ofiarami. Zapomnieliśmy o tym, że Labirynt raz jest więzieniem czy Hadesem, a raz placem tanecznym. Taniec Ariadne z tarczy Achillesa, jak i taniec geranos, który zatańczył Tezeusz, uciekając z Knossos na Delos, a który to taniec miał przypominać Labirynt i jakoś przecież sam Labiryntem był, posiadał cechę pośród tańców grec- 
kich niezwykłą, tańczyli w nim bowiem wspólnie chłopcy i dziewczynki (Scholia in Iliadem XVIII, 591; 1877, t. IV, s. 202). Mało, tańczyli w nim młodzieńcy, to znaczy tacy chłopcy, którzy mieli się wkrótce stać mężczyznami, i tańczyły dziewczynki w wieku zdatnym do zamążpójścia. To nie jest taniec godowy, nie tańczą ze sobą przyszli małżonkowie, co by jeszcze może jakoś się mieściło w głowie, ale tańczą ze sobą młodzi, którzy zapewne żenić się ze sobą nie będą. Nie będziemy w błędzie, jeśli powiemy, że takie widoki poza sceną zapewne uznane by zostały za głęboko gorszące. Być może powinniśmy przywołać tutaj drugi obraz.

Hefajstos. A więc, jak wiemy, Hefajstos miał za żonę najpiękniejszą z bogiń, choć zwycięstwo Afrodyty w słynnym sądzie o piękność może budzić wątpliwości, a szczególne wątpliwości może budzić osoba sędziego. Raczej sąd ów dowodził tego, co dla wszystkich było jasne. No tak, Hefajstos, powiedzmy sobie, już taki piękny nie był, bóg rzecz jasna, ale raczej uchodził wśród bogów za mruka bez ogłady i towarzyskich manier. A do tego jeszcze Hefajstos był kulawy. Stąd nieraz, jak choćby w pierwszej księdze Iliady, patrząc na Hefajstosa, wszyscy bogowie wpadali w bardzo pożyteczną dla ogólnego współżycia, ale bardzo kłopotliwą dla pożycia małżeńskiego Hefajstosa wesołość. Afrodyta oczywiście darzyła Hefajstosa szacunkiem, ale szacunek nigdy, mimo tego, że raczej wystarczał Hefajstosowi, nie wystarczał Afrodycie. No dobrze, nie będziemy Hefajstosa dręczyć, nie wspomnimy Adonisa, nie wspomnimy Anchizesa, przypomnijmy tylko tę opowieść, która nas interesuje najbardziej. Słabość kobiet do wojowników - bez względu na to, czy jest faktem, czy tylko przetworzoną literacko tęsknotą wojujących mężczyzn, którzy w chwili kłopotliwego zawieszenia poszukują dla swoich działań racji - jest tematem obecnym w literaturze, zarówno tej zacnej, jak i tej zacnej w mniejszym stopniu. A więc romans Afrodyty z Aresem. Helios wszystkowidzący, jak to $\mathrm{z}$ Heliosem bywa, dostrzegł i to, czego dostrzec nie należało. Czynności, które zawładnęły Afrodytą i Aresem do tego stopnia, że nie zauważyli spoglądającego na nich wszystkowidzącego Heliosa, rzecz jasna tańcem możemy nazwać jedynie metaforycznie, choć niewątpliwie czynności owe podpadają pod niektóre definicje tańca, głoszące, że jest taniec cielesnym wyrażaniem emocji za pomocą ruchu ujętego w karby rytmu. Helios dostrzegł to, co działo się nie po raz pierwszy, słowem, nie tylko trafiamy na Hefajstosa, którego serce zdradzone krwawi z powodu niewiernej małżonki, ale trafiamy na Hefajstosa, który jakoś musi na sprawy bądź co bądź po części oficjalne zareagować. Hefajstos reaguje po swojemu: konstruuje sieć, w którą Afrodyta z Aresem wpadają. Nago. Z jednej strony linia dowodowa wymaga jasnych $\mathrm{i}$ jednoznacznych argumentów, ale z drugiej strony, ma ona swój sens dopiero wtedy, kiedy zostanie poddana pod osąd. A więc Hefajstos zaprasza bogów, zdaje się wszystkich, a przynajmniej wszystkich najważniejszych, żeby przyjrzeli się niewierności jego żony. Oczywiście zdradzony małżonek nie jest najbardziej rozsądną istotą na ziemi, stąd można się po Hefajstosie spodziewać posunięć nie do końca przemyślanych - ale żeby aż do tego stopnia? Bogowie są zachwyceni i raczej uroczystość przeciągają, jedynie 
Posejdon czuje się nieswojo, właściwie nie wiemy dlaczego, i zaczyna przekonywać Hefajstosa, żeby Aresa z Afrodytą ze swojej sieci wypuścił. Hermes zatapia się w marzeniach, Apollo chciałby zostać Aresem, ale za sprawą zawstydzonego Posejdona robi się nieprzyjemnie i z wolna również pozostali bogowie z niechęcią przyłączają się do argumentów Posejdona. Kiedy Hefajstos unosi sieć, Ares z Afrodytą uciekają. Scena, swoją drogą nie tylko ta z udziałem Hefajstosa, nawet jeśli temu w ogóle nie służy, to to na pewno potrafi: ukazać to, co wstydliwe, albo inaczej: ukazać to, co zakryte, jednocześnie jakoś nadal w zakryciu to pozostawiając. Metoda Hefajstosa przypomina metodę Minosa; łączy ich jeszcze jedno: sieć Hefajstosa była å- - $\varepsilon \iota \rho o v$, nieskończona (Odyseja, ks. VIII, w. 340).

Zaroiło nam się od informacji, może byłoby dobrze je jakoś pozbierać. Zatrzymajmy się póki co przy Dedalu. Jak wiemy od Eustatiusa, Dedal pomagał kobietom, które wplątały się w miłość (Pazyfae jest tutaj przypadkiem nietypowym). Owe kobiety, biorąc pod uwagę taniec z tarczy Achillesa, raczej dopiero się kobiet $\mathrm{w}$ samych sobie spodziewały, przyglądały się w przerażeniu tym nadchodzącym w nich samych nieubłaganym oznakom dziejowych zmian. Przerażenie, jak o tym wiemy, łączyło się przede wszystkim z nieokreślonym i niezrozumiałym zachwytem. Wszystko się zmieni i w miejsce starego świata pojawi się świat nowy; ci chłopcy malowani, którzy do tańca przychodzą, w białych strojach błyszczących oliwą i boskim spojrzeniu, skrywają w swoim ubiorze przerażającą tajemnicę. Mieczyki, machairai (Grzybowski 2013, s. 135-137), które do tańca ze sobą biorą, w Iliadzie występują nie tyle jako broń, ale jako noże ofiarne. Bo i taka jest rola tańczących dziewczynek. Panien na wydaniu, alfesiboiai, takich, które przyniosą ze sobą wiele wołów. Elementem ubioru dziewczyn, na który Homer zwraca uwagę, jest othone (Grzybowski 2013, s. 133-134), woalka, która z jednej strony skrywa wstyd, a z drugiej - znaczy przejście z jednego do drugiego świata. Kobieta okryta woalką rodzi się, a skoro przed narodzinami jakoś istnieje, narodziny zostają rozpoznane jako wyjście z Hadesu.

Dedal buduje Labirynt, ale Dedal sam w ten Labirynt wpada. Pomoc Ariadne, wątpliwa zresztą, kończy się bowiem dla niej śmiercią (Odyseja,ks. XI, w. 324-325), jest zdradą. Oczywiście, Dedal jest w micie Ateńczykiem, a przecież wcale nim być nie musiał. Pomińmy historię Tezeusza, w końcu sami trochę gramy tę samą, co Tezeusz rolę oślepionych blaskiem wzniosłych szczytów Krety na poły barbarzyńskich wędrowców. Pazyfae - dająca wszystkim światło, Ariadne - przenajświętsza, Fedra - świetlista, i może jeszcze Aigle - błyskająca. Takie imiona noszą bohaterki tej opowieści, a przynajmniej takie imiona nadaje im Tezeusz. Wróćmy do Dedala. Jest budowniczym, rzeźbiarzem i kimś, kto ustawia chóry. Ostatnia funkcja jest wieloznaczna i trzeba by się było jej bez wątpienia przyjrzeć dokładniej; skupmy się na tym momencie, w którym trzy umiejętności Dedala zdają się jakoś łączyć. Lub współzawodniczyć. Może nie trop, ale drobną wskazówkę daje nam Atenajos, który twierdzi, że greckie rzeźby naśladowały figury taneczne (Atenajos, $629 \mathrm{~B}$ ). Budowa miasta, określenie miejsc świętych i wyznaczenie granic między tym, co 
ludzkie, i tym, co boskie. Wiemy od uczonych, ile trzeba było zachodu, aby obłaskawić obróbkę metali. Kowale, alchemicy i magowie. Sily wyrwane ziemi poddane na służbę człowiekowi. Kusi przecież, żeby podobnej opowieści poszukać dla choreografów. Powiedzmy sobie, nas kusi, a Eurypidesa skusiło. W Bakchantkach. Nie wiemy, na ile Eurypidesa skusiło pierwszego, na pewno przed Eurypidesem ten sam mit opowiedział Ajschylos, a i również wśród malowideł na wazach możemy odnaleźć znane z tragedii Eurypidesa imiona głównych bohaterów. Nie możemy opowiedzieć wszystkiego, zatem w wielkim skrócie: $\mathrm{w}$ Tebach pojawia się Dionizos wraz z chórem bakchantek. Kobiety wpadają w szał i opuszczają miasto, by tańczyć na stokach Kithajronu. Na temat ich tańca mamy jedynie wyobrażenia: odchylone głowy, ogień we włosach, węże i ogłuszający dźwięk aulosów. Może i widzowie Bakchantek odnajdywali w tych opisach jakieś znajome sobie obrazy, my jesteśmy zupełnie bezradni. Jedno, co wydaje się pewne, to to, że taniec bakchantek staje się u Eurypidesa w pewnym momencie tańcem jako takim i choć patrzymy w stronę obrzędów Dionizosa, jesteśmy w świecie, w którym Dionizos jest prawodawcą. Albo inaczej - jesteśmy w świecie, którego granice Dionizos zakreśla. Czego chce Penteus? Schwytać i unieruchomić w imię państwa, wraz z przyjściem Dionizosa Teby tracą bowiem rację bytu, nie tylko dlatego, że miasto pozbawione kobiet długo nie przetrwa, ale dlatego, że racja istnienia państwa przestaje być racją. Jak to się skończy, wiemy - Penteus pójdzie na Kithajron, sam przebrany za bakchantkę, gdzie przez bakchantki rozszarpany zginie. Zginie tak, jak ginął w mitach Dionizos, żeby przypomnieć choćby mit o Zagreusie i Tytanach. Śmierć Penteusa sprawi jednak, że kobiety wrócą do domów i miasto będzie mogło dalej trwać. Do czasu następnej, już zapewne wedle reguł wyznaczonych przez mit, ucieczki kobiet na Kithajron. I do czasu kolejnej, zapewne przez obrzęd złagodzonej, śmierci Penteusa. Choreograf, bo taką paralelę tutaj rozpisujemy, powstrzymuje ruch, aniżeli ten ruch budzi; jego zadaniem jest sprawić, by to, co nieokreślone i nieskończone zarazem, nieskończone, znoszące bowiem wszelkie granice, znalazło swój kres. Tym kresem jest najsampierw przedstawienie, udostępnienie możliwości przyglądania. Penteus jest choreografem-wynalazcą, stąd nie można od niego oczekiwać, żeby wiedział na ten temat wszystko, raczej szuka takich metod, które zna z innych miejsc i sztuk, stąd właściwym sposobem poruszenia zdają mu się te ruchy, które przypisywała tańczącym kobietom tradycja. A więc dom, krosna i tkanie. W skrócie, rzecz jasna. Może tak było zresztą z począt$\mathrm{ku}$, że ruchy, jakimi choreograf taniec poskramiał, należały do zwykłego, chciałoby się powiedzieć świeckiego obszaru.

Działanie Penteusa jest naznaczone ryzykiem wielorakim. O jednym, u którego kresu tkwi ofiara Pentheusa, mówi nam Eurypides; jest jeszcze jedno i o nim dowiadujemy się od Pauzaniasza (ks. II, r. 20, a. 4). Pauzaniasz opowiada nam, jak to Dionizos ze swoim orszakiem przybył do Argos i tam napotkał przeciwnika potężniejszego niż Pentheus, a może też przeciwnika innego rodzaju, Perseusza. Perseusz, tak jak Pentheus, tańców Dionizosa przyjąć nie chce, ale inaczej niż Pen- 
theus z orszakiem Dionizosa zwycięża. Wśród bakchantek, które z ręki Perseusza giną, jest jedna szczególna, nazywa się Choreia, to znaczy Taniec. O czym mówimy? O tym, że choreografia, jako siła krępująca i powściągająca, jakoś dąży do zdobycia władzy, jest dla tańca siłą wrogą, ale jak to z wrogością przecież jest, nie tylko w tej, ale w innych również sytuacjach - wróg swojego wroga uobecnia. Ale wróg, nawet jeśliby uznać, że niechcący, jakoś przecież dąży do tego, żeby swojego wroga nie tyle uobecnić, co zniszczyć. Opowieść o Perseuszu pojawia się zresztą również w micie znacznie nam lepiej znanym. Gorgony i najmłodsza z nich Meduza. Znamy jej przerażające przedstawienia (Hezjod, Narodziny bogów, w. 270-283), ale są i inne. Pauzaniasz (ks. II, r. 21, a. 5) przekazuje nam oto opowieść, wedle której Gorgona była piękną królewną, którą podstępnie zamordowali dowódcy wojsk Perseusza. Królewną tak piękną, że jej odcięta głowa lśniła oślepiającym blaskiem. Perseusz nie mógł się jej pozbyć nie tyle ze względu na jej niesłychane zdolności bojowe, ile ze względu na jej piękno właśnie. Spojrzenie, które później w micie stanie się spojrzeniem petryfikującym, unieruchamia w zachwycie. Pindar Gorgony umieszcza w krainie Hyperborejczyków (Oda pytyjska, ks. X, w. 34-55), a więc trochę w raju. Tam dokonuje się zbrodnia. Pouczeni przez antropologów dostrzegamy w mieczu Perseusza cechy falliczne, a w śmierci Meduzy związany z małżeństwem rytuał przejścia (Topper, 2010), ale jeśli każda interpretacja, nawet antropologiczna, jest poniekąd przekładem, sięgnijmy jeszcze na chwilę do oryginału. Trzy zatopione w tańcu dziewczyny. I najmłodsza z nich, która w tańcu gubi krok. I to zgubienie kroku, jak by na to nie patrzeć, jest zaproszeniem. Tu się pojawia historia i tu się pojawia państwo. I w tym miejscu pojawia się polityka. Ta grecka, która na dobrą sprawę znaczy tyle, co troska o ustawienie chórów tanecznych. Jak widać z niewinnej bądź co bądź opowieści o choreografie, który w imię zapewne rozmaitych technik tanecznych sprawil, że techniki te przestały być tanecznymi, słowem - z opowieści o pewnym, dość często spotykanym typie nadgorliwego choreografa, który by ocalić taniec, sam siebie winien poświęcić, a miast siebie, poświęca taniec - trafiliśmy w obręb polityki, która nie tylko nie chce zajmować się ustawianiem chórów, ale nawet nie wie o tym, że na tym polega jej rola. Kto wie, czy właśnie z tego powodu z polityką nie mamy tylu problemów. Państwo, które przestaje się zajmować tańcem, jakoś państwem być przestaje.

\section{Bibliografia}

\section{Teksty źródłowe}

Aristoteles (1966), Physica, W.D. Ross (red.), Oxford. Wydanie polskie: Arystoteles (1990), Fizyka, tłum. K. Leśniak, [w:] Arystoteles, Dzieła wszystkie, tom II, PWN, Warszawa.

Athenaeus (1950), Deiphnosophistes, t. I-VII, Harvard University Press, Harvard. Wydanie polskie: Atenajos (2012), Uczta mędrców, tłum. K. Bartol, J. Danielewicz, Wydawnictwo Poznańskie, Poznań. 
Euripides (1978), Tragoediae, t. I-IV, Harvard. Wydanie polskie: Eurypides (20052007), Tragedie, t. I-IV, tłum. J. Łanowski, Prószyński i S-ka, Warszawa.

Eustachius (1830), Eustathii Archiepiscopii Thessalonicensis Comentarii ad Homeri Iliadem, t. IV, Lipsiae.

Hezjod (1999), Narodziny bogów (Theogonia), Prace i dni, Tarcza, tłum. i oprac. J. Łanowski, Prószyński i S-ka, Warszawa.

Homer (1994), Odyseja, tłum. J. Parandowski, Poznań.

Pauzaniasz (1973), Wędrówka po Helladzie, W świątyni i w micie, tłum. J. Niemirska-Pliszczyńska, Ossolineum, Wrocław.

Plutarch (2004), Żywoty równoległe, t. 1: Tezeusz, Romulus i ich porównanie, Likurg, Numa i ich porównanie, tłum. K. Korus, Prószyński i S-ka, Warszawa.

Pindar (1981), Wybór poezji, oprac. A. Szastyńska-Siemion, Zakład Narodowy im. Ossolińskich, Wrocław.

Scholia graeca in Homeri Iliadem (1877), oprac. W. Dindorf, Oxonii, [bmw].

\section{Słowniki}

Beekes R. (2010), Etymological Dictionary of Greek, Brill, Leiden-Boston.

Chantraine P. (1968), Dictionnaire étymologique de la langue grecque. Histoire des mots, Klincksieck, Paris.

Frisk H. (1960), Griechisches etymologisches Wörterbuch, Heidelberg.

Liddell H.S., Scott R. (1996), A Greek-English Lexicon, Clarendon Press, Oxford.

Matthia A. (1861), Lexicon Euripideum, Lipsiae.

\section{Literatura przedmiotu}

Grzybowski J. (2011), Wykład o improwizacji, [w: ] „Wykłady/rozmowy o improwizacji tańca”, Warszawa.

Grzybowski J. (2013), Taniec labiryntu albo o tym, co wyryt Przestawny Kulawiec na środku tarczy Achillesa, „Studia Choreologica”, t. XIV.

Grzybowski J. (2015), Taniec żurawi - zwięzłe sprawozdanie z prowadzonych badań, „Studia Choreologica”, t. XVI.

The Iliad. A commentary (1991), G.S. Kirk, R. Janko, M.W. Edwards, B. Hainsworth, N. Richardson (red.), t. I-VI, Cambridge University Press, Cambridge.

Topper K. (2010), Maidens, fillies and the death of Medusa on a seventh-century pithos, „The Journal of Hellenic Studies”, t. 130.

Wunderlich H.G. (2003), Tajemnica Krety. Dokąd byk porwat Europę, czyli o korzeniach kultury europejskiej, tłum. I. Kania, Universitas, Kraków.

\section{Summary}

The word "choreography", if we try to dissect it, contains two words. Two words but also somehow two things. Dancing and writing. I would like, from this perspective, to look at the three Greek images of the stage. The first picture is a labyrinth, the famous mythical Cretan building, which likes to appear in myths as the dance floor. The second picture is a spectacle prepared for the Olympic gods by Hephaistus, in which the lead roles were brilliantly played by Aphrodite 
with Ares, the third picture taken from the Euripides'es Bacchae and he is in my sense the brace of the whole story, is a painting in which dance and writing are facing each other as deadly enemies. The choreographer, the one who sets the stage, also establishes the central place of the state. Therefore, I would like to see in the choreographic act the founding and, in a strict sence, political action. If man is, as Aristotle said, a political animal, in this act in which polis derives from the mythical past, in which the gods and heroes depart, or otherwise, in which the gods and heroes occupy the spheres given them by the Republic, in this act of establishment I would like to look through the stage not only in the nature of dance, but also in the nature of man. 